\title{
Role of atrial natriuretic peptide in the suppression of lysophosphatydic acid-induced rat aortic smooth muscle (RASM) cell growth
}

\author{
P.M. Baldini, ${ }^{1}$ P. De Vito ${ }^{1}$, F. D'aquilio, ${ }^{1}$ D. Vismara, ${ }^{1}$ F. Zalfa, ${ }^{1,3}$ \\ C. Bagni, ${ }^{1,3}$ R. Fiaccavento ${ }^{2}$ and P. Di Nardo ${ }^{2}$ \\ ${ }^{1}$ Department of Biology, University of Rome 'Tor Vergata', Rome, Italy; ${ }^{2}$ Department of Internal Medicine, Laboratory of \\ Cellular and Molecular Cardiology; University of Rome "Tor Vergata", Rome, Italy; ${ }^{3}$ Istituto di Neuroscienze Sperimentali. \\ Fondazione Santa Lucia, IRCCS, Rome, Italy
}

Received 23 July 2004; accepted 14 October 2004

\begin{abstract}
Lysophosphatidic acid (LPA) is a lipid mediator with multiple biological functions. In the present study we investigated the possible role of atrial natriuretic peptide (ANP), a hormone affecting cardiovascular homeostasis and inducing antimitogenic effects in different cell types, on LPA-induced cell growth and reactive oxygen species (ROS) production in rat aortic smooth muscle (RASM) cells. Both LPA effects on cell growth and levels of ROS were totally abrogated by physiological concentrations of ANP, without modifying the overexpression of LPA-receptors. These effects were also affected by cell pretreatment with wortmannin, an inhibitor of phosphatidylinositol 3-kinase (PI3K). Moreover, the LPA-induced activation of Akt, a downstream target of PI3K, was completely inhibited by physiological concentrations of ANP, which were also able to inhibit p42/p44 phosphorylation. Taken together, our data suggest that PI3K may represent an important step in the LPA signal transduction pathway responsible for ROS generation and DNA synthesis in RASM cells. At same time, the enzyme could also represent an essential target for the antiproliferative effects of ANP. (Mol Cell Biochem 272: 19-28, 2005)
\end{abstract}

Key words: atrial natriuretic peptide, lysophosphatidic acid, phosphatidylinositol 3 kinase, reactive oxygen species

\section{Introduction}

The atrial natriuretic peptide (ANP), a hormone known to affect cardiovascular homeostasis [1], has been demonstrated to elicit antiproliferative effects in several cell types, such as cardiac fibroblasts [2], hepatoblastoma cells (HepG2) [3] and vascular smooth muscle (VSM) cells [4] with mechanisms not established yet.

ANP promotes its biological effects interacting with specific receptors located on plasma membrane of target cells: NPR-A receptors, able to activate the guanylate cyclase/guanosine $3^{\prime}, 5^{\prime}$-cyclic monophosphate (cGMP) system
[1], and NPR-C receptors, negatively coupled to intracellular adenosine $3^{\prime}-5^{\prime}$-cyclic monophosphate (cAMP) modulation or positively coupled to membrane lipid turnover through the activation of specific phospholipases [1, 5]. ANP physiological concentrations $\left(10^{-9}-10^{-11} \mathrm{M}\right)$ may induce antimitogenic effects in several cell types, including rat aortic smooth muscle (RASM) cells [6], through NPR-C receptors and involve different transduction pathways [7, 8].

Several molecules derived from phospholipids have been recently found to modulate cell growth [9] and among them, the lysophosphatidic acid (LPA), a bioactive lipid mainly released from activated platelets [10]. LPA displays its 
biological activities through three receptors, $\mathrm{LPA}_{1}, \mathrm{LPA}_{2}$ and $\mathrm{LPA}_{3}$ [11], and plays an important role in the modulation of cell growth in several cell types [12-15].

LPA promotes VSM cell proliferation by activating several signaling pathways, including the enhancement of phospholipase and mitogen-activated protein kinase (MAPK) activities [16], and stimulating the phopshoinositide 3-kinases (PI3Ks), a class of lipid kinases that mediate various biological activities linked to cell proliferation and survival [17]. PI3K can also stimulate ROS production [18], which, in turn, take part to transduction pathways linked to LPA [19]. Finally, LPA can play a key role in the phenotypic modulation of VSM cells from the differentiated state to the dedifferentiated one, an important step for the development of atherosclerosis [20]. This pathologic process can also be contributed by ROS production [21].

In light of the increasing interest in possible new interventions capable of ameliorating vascular responses to mitogens, we addressed the question whether: (i) ANP can interfere with LPA-induced DNA synthesis and ROS production; (ii) PI3K can be a crucial hormone target to counteract LPA-induced RASM cells growth.

\section{Methods}

\section{Cell culture}

RASM cells were obtained from the explant of thoracic aorta of 15-week old male Wistar rats by the method of Ross [22]. Cells were cultured in $25-\mathrm{mm}$ plastic tissue culture flasks and grown in Dulbecco's Modified Eagle Medium (DMEM) supplemented with $10 \%$ foetal calf serum (FCS), $100 \mu \mathrm{g} / \mathrm{ml}$ streptomycin and $100 \mathrm{U} / \mathrm{ml}$ penicillin in a humidified atmosphere of $5 \% \mathrm{CO}_{2}$ and $95 \%$ air at $37{ }^{\circ} \mathrm{C}$. RASM cells, harvested once a week with $0.25 \%$ trypsin- $0.02 \%$ EDTA and refed every other day, were used as confluent monolayers after 6-8 days at passage level 4-9.

\section{Cell proliferation studies}

RASM cells were grown in $35 \mathrm{~mm}$ dishes and serum starved for $24 \mathrm{~h}$ before each experiment to rule out possible interferences with cell growth due to serum components and to promote their synchronisation. Cells were washed twice with phosphate buffer saline (PBS) and challenged with different concentrations of LPA $(1-20 \mu \mathrm{M})$. In experiments with $10^{-6}$ $10^{-11} \mathrm{M}$ ANP, $10^{-10} \mathrm{M}$ cANF, $50 \mu \mathrm{M} 8$ 8-Br-cGMP, $50 \mathrm{nM}$ wortmannin, cells were pretreated for $1 \mathrm{~h}$, before LPA addition. Cells were scraped off and counted after Trypan blue staining using a Neubauer modified chamber. $\left[{ }^{3} \mathrm{H}\right]$-thymidine incorporation was used to measure the mitogenic response of RASM cells. After the specific treatments, cells were pulsed with $1 \mu \mathrm{Ci} / \mathrm{ml}\left[{ }^{3} \mathrm{H}\right]$-thymidine and incubated for additional $2 \mathrm{~h}$. RASM cells were scraped off, harvested by centrifugation and treated with $5 \% \mathrm{TCA}$ at $4{ }^{\circ} \mathrm{C}$ for $30 \mathrm{~min}$. The TCA-insoluble fraction was resuspended in $0.1 \%$ SDS in 200 $\mathrm{mM} \mathrm{NaOH}$, and samples, after the addition of $7 \mathrm{ml}$ Optifluor, were counted for radioactivity by a liquid scintillation counter (Tricarb 2180 TR, Packard Instruments, Downers Grove, IL). Cell viability was assessed by Trypan blue staining using a Neubauer modified chamber.

\section{$P C R$ analysis of $L P A$ receptor expression in RASM cells}

Total RNA was extracted by Proteinase K-SDS method [23] from $2 \times 10^{6}$ RASM cells treated or not with $5 \mu \mathrm{M}$ LPA for $6 \mathrm{~h}$ or $10^{-10} \mathrm{M}$ ANP for $1 \mathrm{~h}$. In the experiments with LPA + ANP, cells were pretreated with ANP for $1 \mathrm{~h}$, then washed twice in PBS and resuspended in the same buffer before LPA addition for $6 \mathrm{~h}$. Total RNA quantity and quality were assessed by measuring UV absorbance at $260 \mathrm{~nm}$ and by electrophoresis on agarose/formaldehyde gel. One microgram of total RNA was DNase treated (Amersham Pharmacia Biotech) and reverse-transcribed into cDNA, as previously described [24]. For PCR analysis, an equal amount (10 pg) of an internal control (L22 RNA) was added to each sample before reverse transcription and detected with specific oligonucleotides, as reported by Zalfa et al. [25]. An aliquot of RT products $(1 \mu \mathrm{l})$ was PCR-amplified using $200 \mu \mathrm{M}$ of dATP, dGTP, dTTP and $10 \mu \mathrm{M}$ of dCTP, $0.5 \mathrm{U}$ of DyNAzyme II DNA polymerase (Finnzymes), $0.2 \mu \mathrm{Ci}[\alpha-$ ${ }^{32} \mathrm{P}$ ]dCTP (Amersham Pharmacia Biotech; $3000 \mathrm{Ci} / \mathrm{mmol}$ ) and 20 pmol of each primer designed to amplify the mRNA of rat LPA receptors: $\mathrm{LPA}_{1}$ (NM053936), sense primer 5'-GGACACCATGATGAGCCTTC-3', antisense primer 5' GGGCTACCAAGCAAGTTCATC-3'; LPA 2 (NM020028), sense primer 5'-ATGGGCCAGTGCTACTACAAC-3', antisense primer 5'-GCATTGACCAGTGAGTTGGC-3'; and $\mathrm{LPA}_{3}$ (NM023969), sense primer 5'-CCAACGT CCTCTCTCCGCAC-3' , antisense primer 5'-GCAGATCAT CTTCCGCATGG-3'. All transcripts were amplified as follows: $94^{\circ} \mathrm{C}$ for $4 \mathrm{~min}$, unsaturated cycle numbers (25 cycles for $\mathrm{LPA}_{1}, 30$ cycles for $\mathrm{LPA}_{3}, 15$ cycles for GAPDH and 22 cycles for L22 cDNAs) at $94{ }^{\circ} \mathrm{C}$ for $1 \mathrm{~min}$, $58^{\circ} \mathrm{C}$ for $1 \mathrm{~min}$ and $72^{\circ} \mathrm{C}$ for $1 \mathrm{~min}$, followed by a final extension at $72{ }^{\circ} \mathrm{C}$ for $10 \mathrm{~min}$. The expression levels of the three receptor mRNAs in RASM cells were quantified by normalising their respective mRNA levels to L22 mRNA and the housekeeping rat GAPDH mRNA (ID: NM017008; sense primer 5'-GGACATTGTTGCCATCAACG-3', antisense primer $5^{\prime}$-CCTTCCACGATGCCAAAGTT-3') levels. The amplified fragments were separated on $5 \%$ polyacrylamide gel and quantified by a Phosphor-Imager (Molecular Imager FX, Bio-Rad, Hercules, CA). 


\section{Detection of ROS in RASM cells}

Cells $\left(1 \times 10^{6}\right)$ were synchronised as reported earlier, resuspended in PBS buffer and loaded with the fluorescent indicator Dichlorofluorescein Diacetate (DCF-DA) at final concentrations of $10 \mu \mathrm{M}$ for $60 \mathrm{~min}$ at $37^{\circ} \mathrm{C}$ in the dark [26]. After the incubation with the fluorescent dye, RASM cells were washed twice with PBS buffer, centrifuged for 5 min at $1500 \mathrm{rpm}$ at room temperature, resuspended in PBS and challenged with LPA. In the experiments with different effectors, cells were pretreated for $1 \mathrm{~h}$ at $37^{\circ} \mathrm{C}$ in the dark. A sample of $1 \times 10^{5}$ cells was used to monitor ROS production. Fluorescence was measured under continuous magnetic stirring and controlled temperature $\left(37^{\circ} \mathrm{C}\right)$ in a Perkin-Elmer luminescence spectrometer (model LS-5) equipped with a chart recorder (model R 100A), with excitation wavelength at $485 \mathrm{~nm}$ and emission wavelength at $530 \mathrm{~nm}$ using 5 and $10 \mathrm{~nm}$ slits respectively, for each light path. Results are expressed as fluorescence intensity, reported as fluorescence units (F.U.), of cells loaded with only DCF-DA (control) or also treated with $300 \mu \mathrm{M} \mathrm{H}_{2} \mathrm{O}_{2}$ for $1 \mathrm{~h}$ as positive control. When requested, RASM cells were pretreated with ANP and $50 \mathrm{nM}$ wortmannin for $1 \mathrm{~h}$ before LPA addition.

\section{Microscopy for ROS generation}

ROS generation was carried out on glass coverlips. Cells were labelled with $5 \mu \mathrm{M}$ (final concentration) of peroxidesensitive fluorescent dye $2^{\prime}, 7^{\prime}$ dichlorodihydrofluorescein diacetate (DCFH-DA) and then incubated for $6 \mathrm{~h}$ in the presence or absence of LPA and ANP. Intracellular fluorescence was monitored using an inverted fluorescence microscope (Leica) with a $20 \times$ objective. Signal-based averaging was used to quantitate the fluorescence signal from five to six fields of cells.

\section{PI3 kinase activity assay}

Cells were grown as reported earlier and then challenged with $5 \mu \mathrm{M}$ LPA in the presence or absence of ANP or wortmannin. The reaction was terminated by washing with $4{ }^{\circ} \mathrm{C}$ PBS and lysis of cells. Lysis buffer consisted of (mM): 50 TRIS$\mathrm{HCl}$ (pH 7.4), $150 \mathrm{NaCl}, 1 \mathrm{Na}_{2} \mathrm{VO}_{3}, 2$ EDTA, $1 \mathrm{MgCl}_{2}$, $1 \mathrm{CaCl}_{2}$ with $30 \mathrm{nM}$ leucopeptin and $1 \% \mathrm{NP}-40$ (v/v). Lysate was centrifuged at $12000 \times \mathrm{g}$ for $20 \mathrm{~min}$ at $4{ }^{\circ} \mathrm{C}$. Lysate aliquots containing equal amounts of protein were incubated with agarose-conjugated antibody to phosphotyrosine (PY 20) for $2 \mathrm{~h}$ at $4{ }^{\circ} \mathrm{C}$. Immunoprecipitate was washed three times with PBS and PI3K activity was finally measured as described [27].

\section{Immunoblots}

RASM cells grown in six-well plates $\left(10^{5}\right.$ cells/well $)$ were synchronised as reported earlier, resuspended in PBS buffer and challenged with LPA. When requested, cells were pretreated with $10^{-10} \mathrm{M}$ ANP and/or $50 \mathrm{nM}$ wortmannin, before LPA addition for $30 \mathrm{~min}$. The reaction was stopped and cells were washed twice with PBS, centrifuged at $1500 \mathrm{rpm}$ for $5 \mathrm{~min}$ and the pellet was lysed with sample buffer containing: $10 \%$ sodium dodecyl sulfate (SDS), $10 \%$ glycerol, $100 \mathrm{mM}$ dithiotreitol, $5 \% \beta$-mercaptoetanol, $1 \%$ bromophenol blue, 2 mM EDTA, 1 mM sodium vanadate, $50 \mathrm{mM}$ Tris$\mathrm{HCl}$ (pH 6.8), plus a cocktail of protease inhibitors (1 mM phenylmethylsulfonylfluoride, $1 \mu \mathrm{g} / \mathrm{ml}$ pepstatin, $10 \mu \mathrm{g} / \mathrm{ml}$ leupeptin, $10 \mu \mathrm{g} / \mathrm{ml}$ aprotenin) in ice for $30 \mathrm{~min}$. The lysate was centrifuged at $13000 \mathrm{rpm}$ for $5 \mathrm{~min}$; the supernatant was boiled for $5 \mathrm{~min}$ and then stored at $-70^{\circ} \mathrm{C}$. The protein content of cell lysates was evaluated by the method of Lowry [28]. Equal amounts of whole cell lysate $(30-50 \mu \mathrm{g})$ were subjected to $8 \%$ acrylamide SDS-PAGE, transferred onto nitrocellulose membranes and probed with primary antiphospho- and total p42/44 MAP kinases antibodies (both 1:1000) or anti-phospho- and total Akt antibodies overnight at $4{ }^{\circ} \mathrm{C}$ (Santa Cruz, Biotechnology Inc., CA). A horseradish peroxidase-conjugated secondary antibody (1:2500) was used for $1 \mathrm{~h}$ at room temperature. Membranes were then analysed by ECL assay (Amersham Pharmacia Biotech, Italia, $\mathrm{MI}$ ); each experiment was repeated at least three times.

\section{Materials}

Dulbecco's Modified Eagle Medium (DMEM), trypsin 2.5\%, glutammine, penicillin $(10000 \mathrm{UI} / \mathrm{ml})$ and streptomycin $(10000 \mu \mathrm{g} / \mathrm{ml})$ were from Eurobio Laboratoires (Le Ulis Cedex, France). Foetal Calf Serum (FCS) was from GIBCO (Grand Island, NY, USA). $\left[{ }^{3} \mathrm{H}\right]$-myristic acid (specific activity: $53 \mathrm{Ci} / \mathrm{mmol})$ and $\left[{ }^{3} \mathrm{H}\right]$-thymidine $(20 \mathrm{Ci} / \mathrm{mmol})$, DNase were from Amersham International (Bucks, UK). LPA (C18:1, 1-oleoyl-sn-glycerol-3-phosphate), ANP, cANF (fragment 4-23), BNP, CNP 8-Br-cGMP, wortmannin, ethylene glycol-bis(2-aminoethylether)- $N, N, N^{\prime}, N^{\prime}$-tetraacetic acid (EGTA), sodium dodecyl sulfate (SDS), ditiotreitol, mercaptoetanol, glycerol, sodium vanadate, phenylmethylsulfonylfluoride, pepstatin, aprotein, leupetin, tris- $\mathrm{HCl}$ were from Sigma Chemicals (St. Louis, MO, USA). $2^{\prime}, 7^{\prime}$-dichlorofluorescein diacetate (DCF-DA) and peroxidesensitive fluorescent dye $2^{\prime}, 7^{\prime}$ dichlorodihydrofluorescein diacetate (DCFH-DA) were from Molecular Probes, Inc. (Eugene, OR). Anti-phosphorylated and total p42/p44 MAPK, anti-phosphorylated and total Akt and PY20 antibodies were purchased from Santa Cruz Biotechnology, Inc (Santa Cruz, CA). Horserardish peroxidase-conjugated secondary antibody and chemiluminescence detection of 
immunoreactive bands ECL reagents were obtained from Amersham Pharmacia Biotech. (Milan, Italy). Primers were purchased from Invitrogen (Milan, Italy).

\section{Statistical methods}

All data are presented as means \pm S.D. Data distribution normality was preliminarily verified by the KolmogorovSmirrov test. Statistical analysis was performed using the Student's $t$-test and, in each group of experiments, the individual treatments were compared singularly vs. the same control. A probability of ${ }^{*} p<0.05$ was accepted as significant difference.

\section{Results}

\section{Role of ANP in LPA-induced cell growth}

To assess the ability of LPA to stimulate RASM cell growth, cells were challenged with LPA in a wide concentration range $(1-20 \mu \mathrm{M})$ and $\left[{ }^{3} \mathrm{H}\right]$ thymidine incorporation and cell number were evaluated at 3,6, $9 \mathrm{~h}$ (Fig. 1a and b). LPA effects

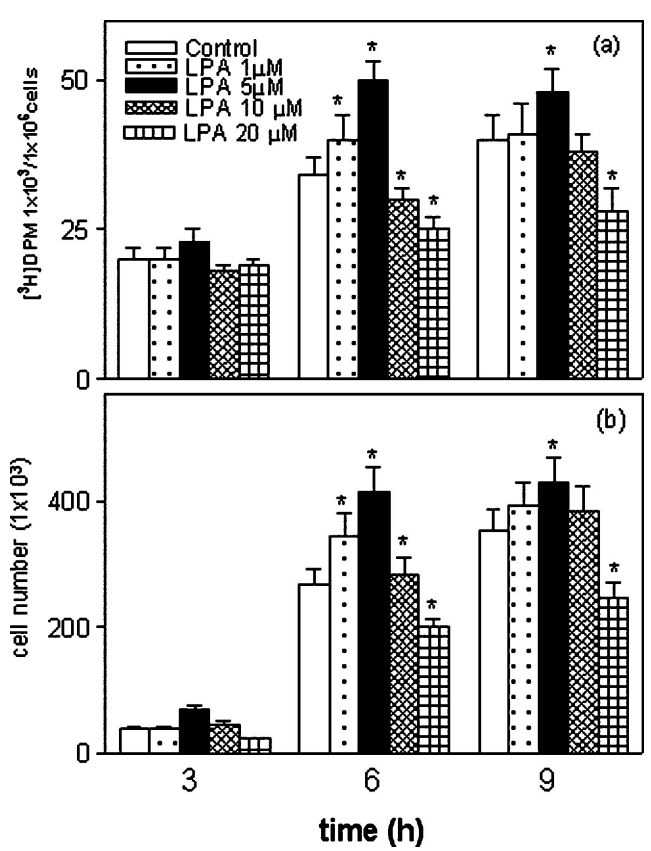

Fig. 1. LPA effects on RASM cell growth. RASM cells, grown in DMEM plus $10 \%$ FCS and serum starved for $24 \mathrm{~h}$ to promote their synchronisation and to rule out possible interferences with cell growth due to serum components, were challenged with a wide concentration range of LPA $(1-20 \mu \mathrm{M})$ for 3, 6 and 9 h. $\left[{ }^{3} \mathrm{H}\right]$ thymidine incorporation (a) and cell number (b) were assessed as reported in the Methods section. Data are reported as mean \pm S.D. of four different experiments. ${ }^{*} p<0.05$, as reported from Student's $t$ test with respect to untreated cells (control). were statistically significant at the lowest concentration used $(1 \mu \mathrm{M})$ and maximal at $5 \mu \mathrm{M}$ at $6 \mathrm{~h}$ vs. untreated cells (about twice the value obtained in the absence of LPA). For this reason, all the following experiments were carried out in the presence of $5 \mu \mathrm{M}$ LPA for $6 \mathrm{~h}$. At higher LPA concentrations $(10-20 \mu \mathrm{M}),\left[{ }^{3} \mathrm{H}\right]$ thymidine incorporation and cell number declined also if cell viability was $>95 \%$ as monitored by Trypan blue exclusion (data not shown).

To test the effect of ANP on both LPA-induced cell growth and $\left[{ }^{3} \mathrm{H}\right]$ thymidine incorporation, RASM cells were pretreated with ANP in a wide concentration range $\left(10^{-6}\right.$ $\left.10^{-11} \mathrm{M}\right)$ (Fig. 2a and b). Our results showed a dosedependent attenuation of LPA-induced cell growth and $\left[{ }^{3} \mathrm{H}\right]$ thymidine incorporation at physiological concentrations $\left(10^{-9}-10^{-11} \mathrm{M}\right)$ of ANP with a maximum at $10^{-10} \mathrm{M}$; conversely, pharmacological concentrations of the hormone $\left(10^{-6}-10^{-8} \mathrm{M}\right)$ were uneffective. The specificity of ANP effect on LPA-induced DNA synthesis was evaluated using other natriuretic peptide such as brain natriuretic peptide (BNP) and C-type natriuretic peptide (CNP). Figure 3 shows that either natriuretic peptides were uneffective to counteract LPA effects.

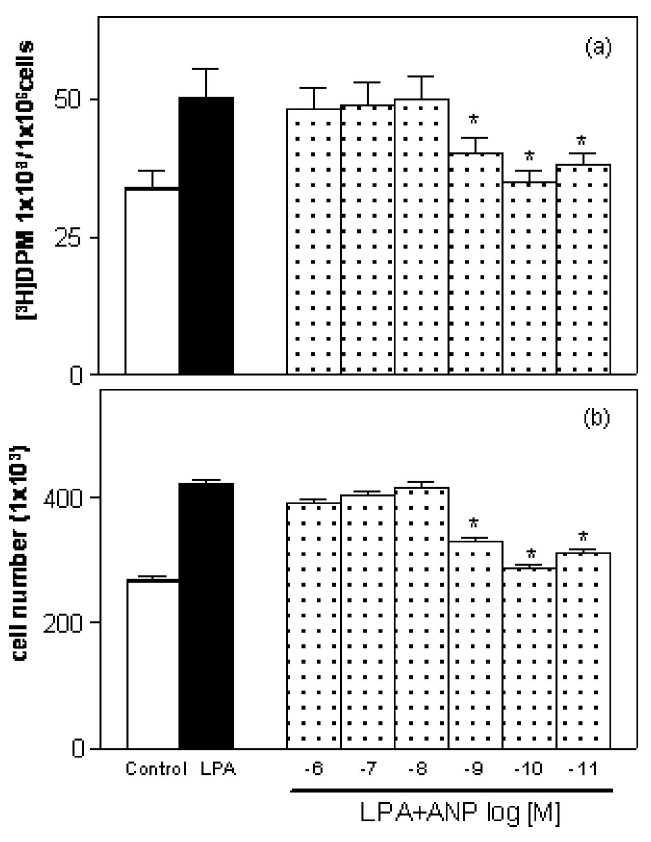

Fig. 2. ANP effects on LPA-induced cell growth. RASM cells, grown in DMEM plus $10 \%$ FCS and serum starved for $24 \mathrm{~h}$ to promote their synchronisation and to rule out possible interferences with cell growth due to serum components, were pretreated with ANP $\left(10^{-6}-10^{-11} \mathrm{M}\right)$ for 1 $\mathrm{h}$ and then challenged with $5 \mu \mathrm{M}$ LPA for $6 \mathrm{~h}$. $\left[{ }^{3} \mathrm{H}\right]$ thymidine incorporation (a) and cell number (b) were assessed as reported in the Methods section. Data are reported as mean \pm S.D. of four different experiments. ${ }^{*} p<0.05$, as reported from Student's $t$ test with respect to untreated cells (control). 


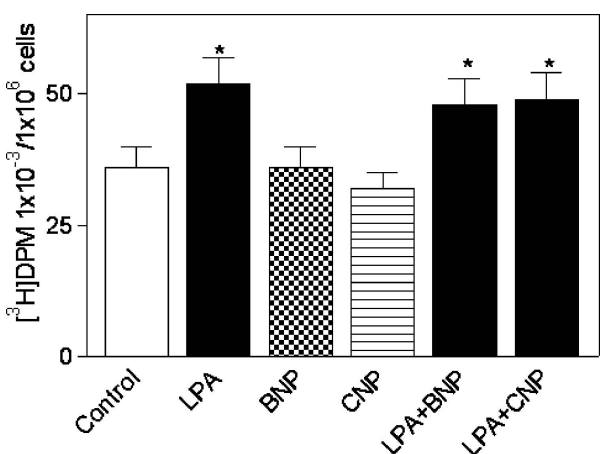

Fig. 3. Effects of BNP and CNP on LPA-induced $\left[{ }^{3} \mathrm{H}\right]$-thymidine incorporation in RASM cells. RASM cells, grown in DMEM plus 10\% FCS and serum starved for $24 \mathrm{~h}$ to promote their synchronisation and to rule out possible interferences with cell growth due to serum components, were pretreated with BNP $\left(10^{-10} \mathrm{M}\right)$ or CNP $\left(10^{-10} \mathrm{M}\right)$ for $1 \mathrm{~h}$ and then challenged with $5 \mu \mathrm{M}$ LPA for $6 \mathrm{~h}$. $\left[{ }^{3} \mathrm{H}\right]$ thymidine incorporation was assessed as reported in the Methods section. Data are reported as mean \pm S.D. of four different experiments. ${ }^{*} p<0.05$, as reported from Student's $t$ test with respect to untreated cells (control).

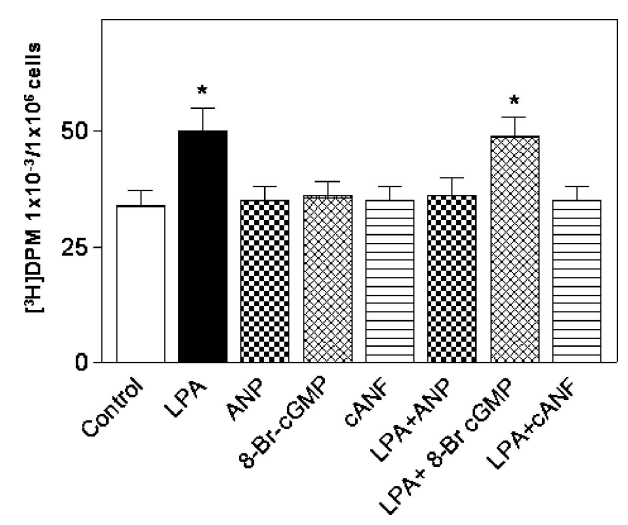

Fig. 4. 8-Br-cGMP and cANF effects on LPA-induced RASM cell growth. RASM cells, grown as reported in Fig. 1, were challenged with $5 \mu \mathrm{M}$ LPA for $6 \mathrm{~h} .50 \mu \mathrm{M} 8$-Br-cGMP or $10^{-10} \mathrm{M}$ cANF or $10^{-10} \mathrm{M}$ ANP were added for $1 \mathrm{~h}$ before LPA addition. $\left[{ }^{3} \mathrm{H}\right]$ thymidine incorporation was assessed as reported in the Methods section. Data are reported as mean \pm S.D. of four different experiments. ${ }^{*} p<0.05$, as reported from Student's $t$ test with respect to untreated cells (control).

To determine which natriuretic peptide (NP)-receptor mediates ANP inhibitory effects on LPA-induced DNA synthesis, experiments were performed with $50 \mu \mathrm{M} 8-\mathrm{Br}-$ cGMP, a not hydrolyzable analogue of cGMP involved in pharmacological effects of the hormone and $10^{-10} \mathrm{M} \mathrm{cANF}$ (4-23), a ring-deleted analogue of ANP, specific activator of the $\mathrm{C}$ receptor. Figure 4 shows that: 8 -Br-cGMP alone as well as in the presence of LPA was uneffective on $\left[{ }^{3} \mathrm{H}\right]$ thymidine incorporation, while only the pretreatment with cANF mimicked ANP effects.

\section{ANP effects on LPA receptor expression}

Since LPA can modulate its biological effects through the involvement of three receptors, $\mathrm{LPA}_{1}, \mathrm{LPA}_{2}$ and $\mathrm{LPA}_{3}$ [11], we carried out experiments to evaluate the role of ANP on LPA-induced receptor expression. Our results, obtained by RT-PCR analysis, showed a significant increase in mRNA levels for $\mathrm{LPA}_{1}$ and $\mathrm{LPA}_{3}$ receptors after LPA treatment, while no significant differences were observed in RASM cells pretreated with ANP, suggesting that ANP did not affect the LPA-induced receptor upregulation (Fig. 5). $\mathrm{LPA}_{2}$ was expressed at an undetectable level.

\section{Role of ANP on LPA-induced ROS production}

The time-course of LPA effects on ROS production is shown in Fig. 6a (inset). LPA induced a significant increase in ROS production already at $30 \mathrm{~min}$ with a maximum at $6 \mathrm{~h}$. To verify whether LPA effects on ROS production could be inhibited by ANP, we performed experiments in the presence or absence of $10^{-8} \mathrm{M}$ (pharmacological concentration) and $10^{-10} \mathrm{M}$ (physiological concentration) ANP. Figure 6a shows that $10^{-8} \mathrm{M}$ as well as $10^{-10} \mathrm{M}$ ANP alone were uneffective on LPA-induced ROS production, while only $10^{-10} \mathrm{M}$ ANP totally abrogated LPA effects. The effects of $10^{-10} \mathrm{M}$ ANP were mimicked by cANF. ROS production was also evaluated by microscopy analysis using peroxide sensitive fluorescent dye (Fig. 6b). The decrease in fluorescence in cells treated with ANP vs. cells challenged with LPA confirmed the hormone effect on ROS production.

\section{PI3K activation is required for both ROS production and DNA synthesis stimulated by LPA: Role of ANP}

To ascertain whether the ability of ANP to counteract LPAinduced ROS production and DNA synthesis in RASM cells could involve the PI3K activation, we examined LPA effects in the presence or absence of wortmannin, an inhibitor of PI3K, in cells treated or not with ANP or cANF. Our results on LPA-induced ROS production (Fig. 7a and b), as well as $\left[{ }^{3} \mathrm{H}\right]$ thymidine incorporation (Fig. 7c and d), in the presence of wortmannin, show that: (i) LPA effects were totally abrogated; (ii) no additive effects were observed in cells treated with ANP or cANF. In addition, to confirm the role of PI3K in this mechanism, enzyme activity was analysed. LPA-induced PI3K activity was inhibited by ANP, while no additive effects were found in the presence of wortmannin plus ANP (Fig. 8). These evidences suggested a crucial role of PI3K in the mechanism by which ANP counteract LPA effects. Since Akt, an important downstream effector of PI3K, is involved in the LPA effects in several cell types 

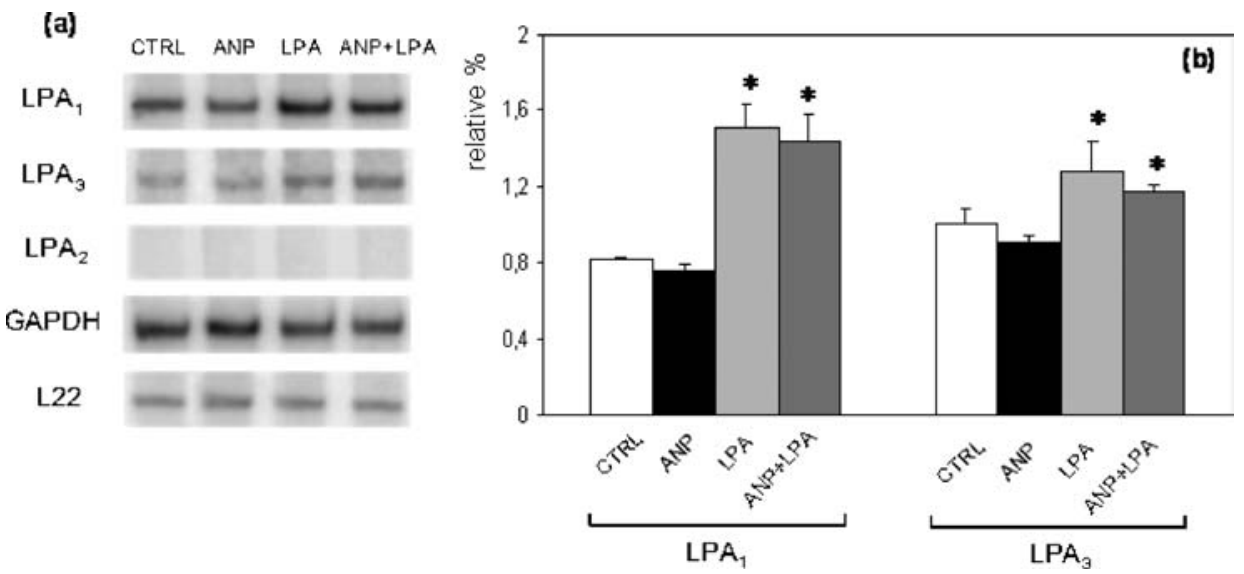

Fig. 5. ANP and LPA effects on $\mathrm{LPA}_{1}, \mathrm{LPA}_{2}$ and $\mathrm{LPA}_{3}$ expression in RASM cells. (a) Total RNA was isolated from $2 \times 10^{6}$ RASM cells treated or not (CTRL) with LPA for $6 \mathrm{~h}$ or $10^{-10} \mathrm{M}$ ANP for $1 \mathrm{~h}$ or pretreated with ANP for $1 \mathrm{~h}$ and challenged with LPA (ANP + LPA) for $6 \mathrm{~h}$. RT-PCR analysis was performed as reported in the Methods Section to amplify LPA receptor mRNAs $\left(\mathrm{LPA}_{1}, \mathrm{LPA}_{2}\right.$ and $\left.\mathrm{LPA}_{3}\right)$ in unsaturated condition. Sizes of PCR products were as follows: $\mathrm{LPA}_{1}, 512 \mathrm{bp} ; \mathrm{LPA}_{2}, 867 \mathrm{bp}$; and $\mathrm{LPA}_{3}, 277 \mathrm{bp}$. (b) The signals of $\mathrm{LPA}_{1}$ and $\mathrm{LPA}_{3}$ cDNAs were quantified and corrected vs. $\mathrm{L} 22$ and GAPDH controls. Values represent the mean \pm S.E.M. of four independent experiments. ${ }^{*} p<0.05$, as from data analysis with respect to untreated cells (CTRL).

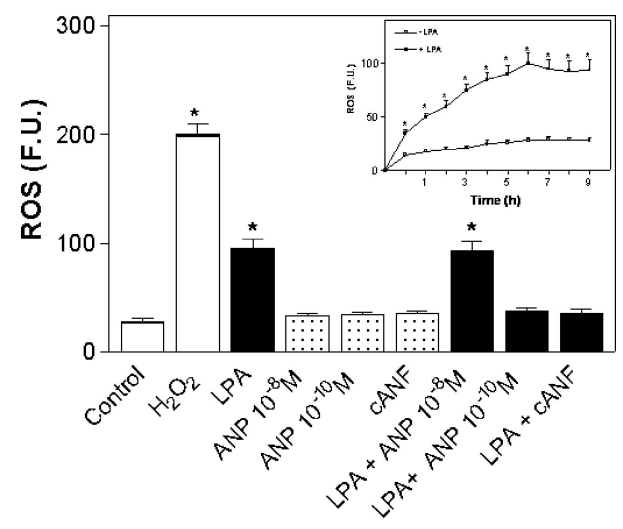

(b)

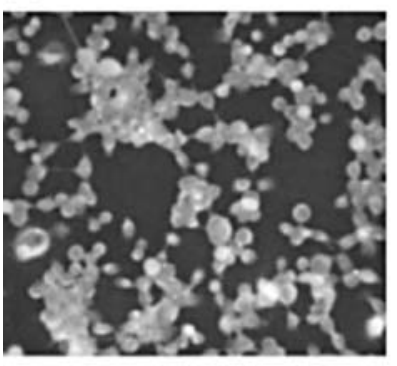

control

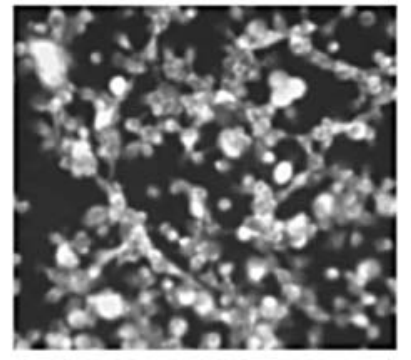

LPA

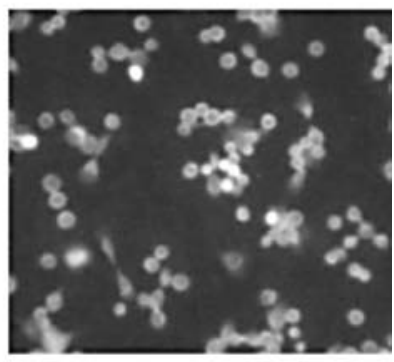

LPA+ANP

Fig. 6. ANP effect on LPA-induced ROS production. (a) RASM cells were labelled with DCF-DA, as reported in the Methods Section, and ROS production was evaluated after cell exposure to $5 \mu \mathrm{M}$ LPA for $6 \mathrm{~h}$. Cells were pretreated with ANP or cANF for $1 \mathrm{~h}$ before LPA addition. Inset: Time course of LPA-induced ROS production in RASM cells. ROS production was evaluated after cell exposure to $5 \mu \mathrm{M}$ LPA for different experimental times. Results are expressed as

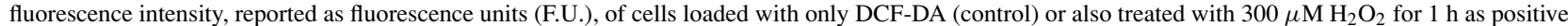
control. Data are reported as mean \pm S.D. of four different experiments. ${ }^{*} p<0.05$, as reported from Student's $t$ test with respect to control. (b) RASM cells were labelled with $5 \mu \mathrm{M}$ (final concentration) of peroxide-sensitive fluorescent dye $2^{\prime}, 7^{\prime}$ dichlorodihydrofluorescein diacetate (DCFH-DA) and then challenged with $5 \mu \mathrm{M}$ LPA in the presence or absence of $10^{-10} \mathrm{M}$ ANP. Images were acquired as reported in Methods section. Original magnification: $20 \times$. 

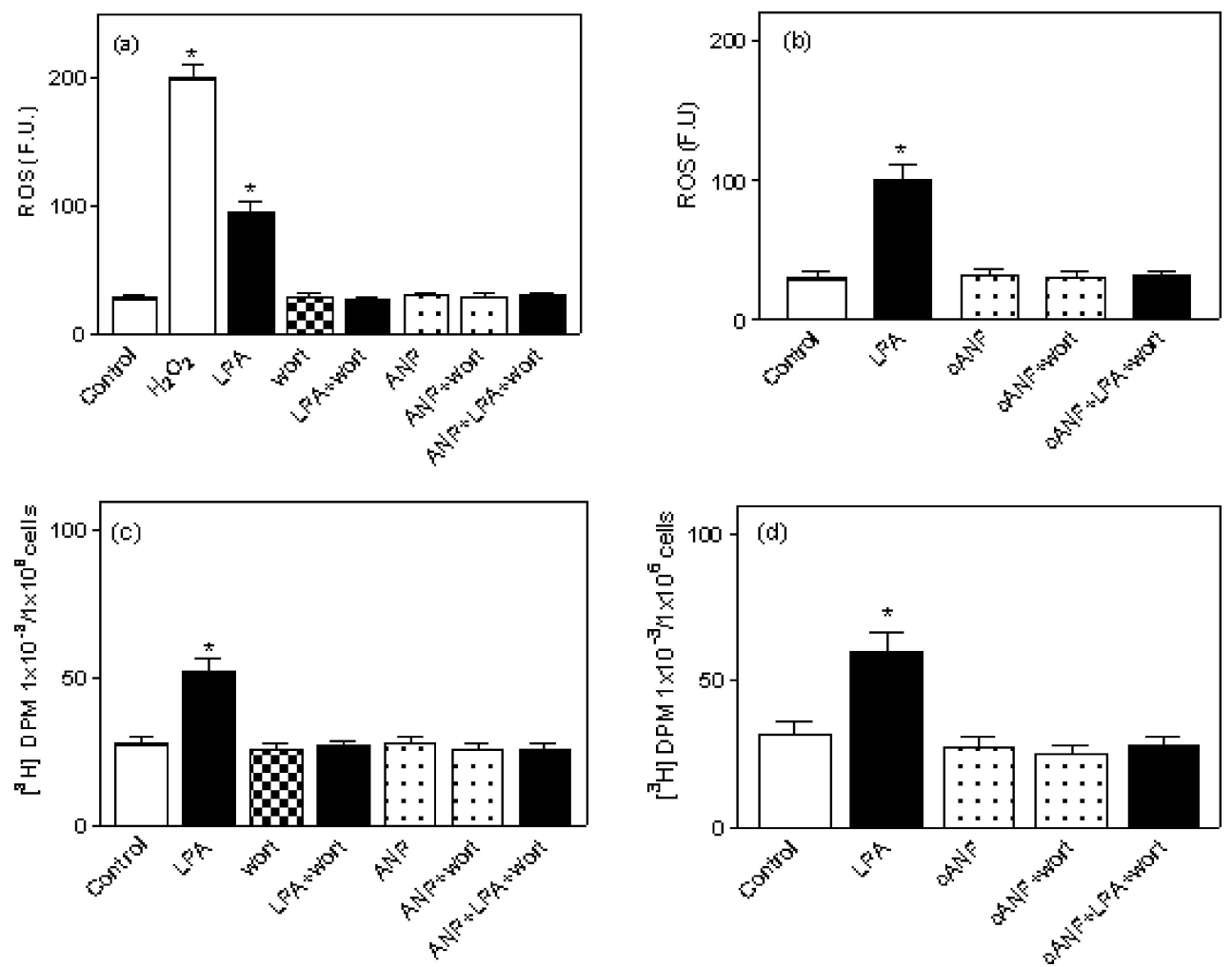

Fig. 7. ANP effects on LPA-induced ROS production and $\left[{ }^{3} \mathrm{H}\right]$ thymidine incorporation in the presence of wortmannin in RASM cells. RASM cells were challenged with $5 \mu \mathrm{M}$ LPA for $6 \mathrm{~h}$. In the experiments with ANP or cANF or $50 \mathrm{nM}$ wortmannin, cells were pretreated for $1 \mathrm{~h}$ before LPA addition. ROS production ( $\mathrm{a}$ and $\mathrm{b}$ ) and $\left[{ }^{3} \mathrm{H}\right]$ thymidine incorporation ( $\mathrm{c}$ and $\mathrm{d}$ ) were assessed as reported in the Methods section. Data are reported as mean \pm S.D. of four different experiments. ${ }^{*} p<0.05$, as reported from Student's $t$ test with respect to untreated cells (control).

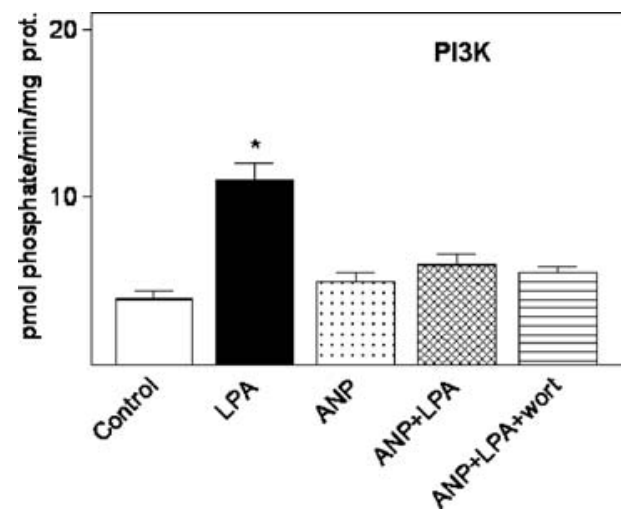

Fig. 8. ANP effects on LPA-induced specific enzyme activity of PI3K. RASM cells, grown in DMEM plus $10 \%$ FCS and serum starved for $24 \mathrm{~h}$ to promote their synchronisation and to rule out possible interferences with cell growth due to serum components, were pretreated with $10^{-10} \mathrm{M}$ ANP or $50 \mathrm{nM}$ wortmannin for $1 \mathrm{~h}$ and then challenged with $5 \mu \mathrm{M}$ LPA for $6 \mathrm{~h}$. PI3K specific activity was measured by kinase activity assay from cell lysates as described in the Methods Section. ${ }^{*} p<$ 0.05 , as reported from Student's $t$ test with respect to untreated cells (control).
[29], ANP ability to counteract LPA-induced Akt phosphorilation was investigated. Immunoblots were performed after four different treatments. Our results showed that Akt phosphorylation induced by LPA was totally inhibited by cell pretreatment with wortmannin or ANP, while ANP plus wortmannin had no additive effects (Fig. 9a). The ANP effects on Akt phosphorylation were mimicked by cANF (Fig. 9b).

\section{ANP effects on LPA-induced p42/44 MAPK phosphorylation}

In order to investigate the ANP-triggered signaling via the MAPK pathways in LPA-stimulated RASM cells, LPA effects on p42/44 MAPK phosphorylation were evaluated in the presence or absence of wortmannin after pretreatment with ANP by immunoblot. Our results showed that ANP inhibited LPA-induced p42/44MAPK phopsphorylation, while no differences were observed in the presence of ANP plus wortmannin (Fig. 10). The same results were obtained with cANF (data not shown). 

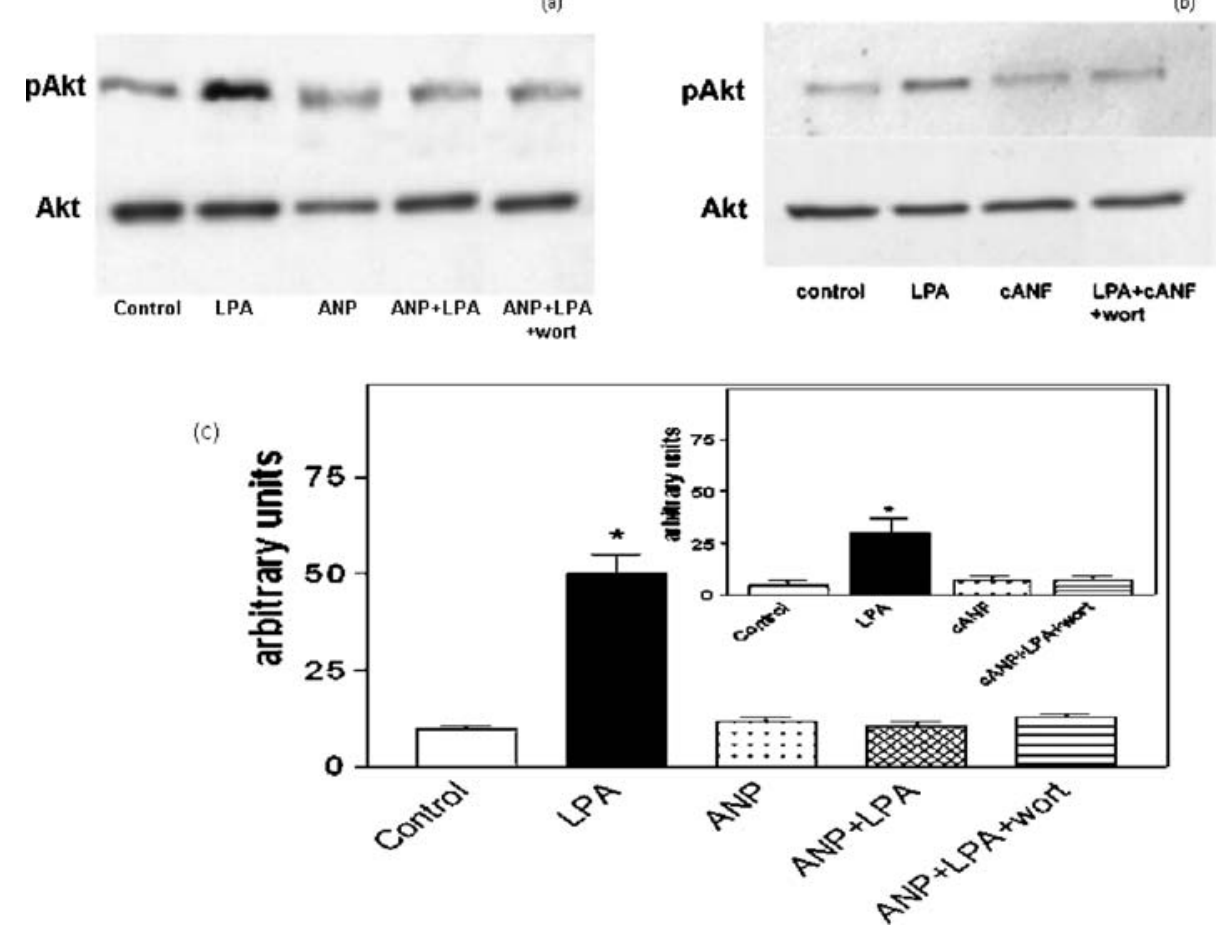

Fig. 9. ANP effects on LPA-induced Akt phosphorylation in RASM cells. Cytosolic extracts prepared from RASM cells were separated by SDS-PAGE. Immunoblotting was performed, as described in the Methods section. Each lane represents lysates from RASM cells treated with $5 \mu$ M LPA for 30 min in the presence or absence of $10^{-10} \mathrm{M}$ ANP or $50 \mathrm{nM}$ wortmannin or $10^{-10} \mathrm{M}$ cANF. A representative experiment is shown, which was repeated three additional times with similar results. Upper lane: phosphorylated Akt; lower lane: total Akt.

\section{pp42/44}

\section{$\mathrm{p} 42 / 44$}
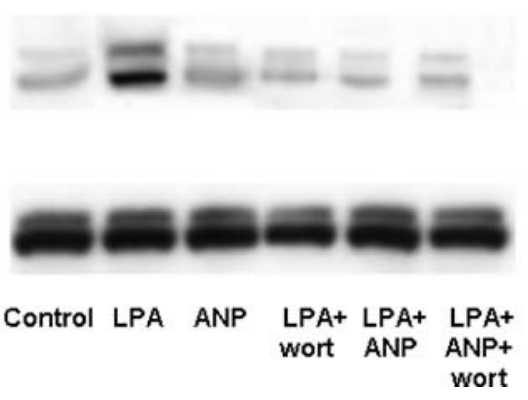

Fig. 10. ANP effects on LPA-induced p42/44 MAPK phosphorylation in RASM cells. Cytosolic extracts from RASM cells were separated by SDSPAGE. Immunoblottings were performed as described in the Methods Section. Each lane was loaded with RASM cell lysate after treatment with $5 \mu \mathrm{M}$ LPA for $30 \mathrm{~min}$ in the presence or absence of $10^{-10} \mathrm{M}$ ANP or $50 \mathrm{nM}$ wortmannin. A representative experiment is shown, which was repeated three additional times with similar results. Upper lane: phosphorylated p42/44 MAPK; lower lane: total p42/44 MAPK.

\section{Discussion}

ANP primary function is directed to decrease blood pressure and regulate renal sodium and water excretion, but the hormone is also endowed with antiproliferative capability after growth factor stimulation [30]. To further investigate this aspect, we investigated the potential role of ANP in preventing LPA-induced cell growth in RASM cells. In fact, excessive VSM cell proliferation is a major feature of the hypertension and atherosclerosis pathogenesis [31].

LPA, a bioactive lipid mainly released from activated platelets [10], can participate in the development of atherosclerotic plaques stimulating VSM cell proliferation [32] and ROS production [19, 33]. Surprisingly, upstream events involved in these processes are still incompletely understood. Our results showed that physiological concentrations of ANP can counteract LPA effects, in terms of ROS generation and cell growth, very likely, involving the NPR$\mathrm{C}$ receptor, as suggested by experiments carried out in the presence of cANF. This effect appears specific for ANP as demonstrated by experiments with other natriuretic peptides, such as BNP and CNP. Interestingly low concentrations of LPA significantly increased RASM cell growth which was inhibited by higher LPA concentrations. This complex response was probably due to the presence of different types of LPA receptors with different affinities for the mitogen with 
opposite mitogenic and antimitogenic effects [34]. Several lines of evidence [35-37] demonstrated that ANP can counteract ROS-induced cell damage by a mechanism that involves the activation of the NPR-A/cGMP system. Our data describe for the first time the ability of physiological concentrations of ANP to contain ROS levels by the involvement of the NPR-C receptor. This appears potentially important since cells which undergo phenotypic modulation, such as RASM cells found in in vivo atheromatous lesions, express a relative large number of NPR-C receptors highly sensitive to physiological concentrations of hormone, while isolated and cultured cells are sensitive to pharmacological concentrations of ANP owing to the reduced NPR-C receptor expression [38]. In this context, our results could be explained by the NPR-C receptor upregulation occurring after long time exposure to LPA. Indeed, the effects herein reported occurred at hormone concentrations as low as $10^{-10} \mathrm{M}$, i.e. in the range of physiological ANP plasma concentrations, while the decreased response to higher concentrations of ANP may be explained by NPR-A receptor down regulation, as reported in other systems [39].

The biological activity of LPA is mediated by, at least, three different G-protein-coupled receptors, namely $\mathrm{LPA}_{1}$, $\mathrm{LPA}_{2}$ and $\mathrm{LPA}_{3}$. Among different LPA intracellular signaling pathways, $\mathrm{PI} 3 \mathrm{~K}$ mediates various biological activities including cell survival, cytoskeletal reorganisation, cytokine gene activation, membrane trafficking and oxidative burst [40], and represents an important upstream effector coupled to VSM cell growth through MAPK activation [17]. Our study shows that physiological concentrations of ANP do not interfere with the LPA-induced receptor upregulation that is responsible for the switching from differentiated to dedifferentiated cell state, an important step for the atherogenic effect of LPA [20]. Indeed, ANP interferes with the LPA signal pathway, including PI3K/ROS, which, in turn, activate the p42/p44 MAPK. Physiological concentrations of LPA can inhibit the activity of the NPR-B receptor specific for C-type natriuretic peptide (CNP), a member of the natriuretic hormone family, suggesting a possible cross-talk between LPA and CNP in cultured fibroblast [41]. Here, we provide evidence for a new link between natriuretic hormones and LPA suggesting that physiological concentrations of ANP can keep under constant repression the atherogenic effects of LPA by inhibiting the lipid effects on PI3K. Consistently, high ANP plasma concentrations, such as observed during cardiovascular diseases, can promote the atherogenic effect of LPA. Our results open new perspectives to clarify the ANP mechanism of action candidating PI3K as a crucial target for the antimitogenic effect of the hormone. These data support the view that ANP can play a key role counteracting the potentially dangerous effects of an excess of cell growth.

\section{References}

1. Anand-Srivastava MB, Trachte GJ: Atrial natriuretic factor receptors and signal transduction. Pharmacol Rev 454: 455-497, 1993

2. Cao L, Gardner DG: Natriuretic peptides inhibit DNA synthesis in cardiac fibroblast. Hypertension 25:227-234, 1995

3. Rashed HM, Sun H, Patel TB: Atrial natriuretic peptide inhibits growth of hepatoblastoma HepG2 cells by means of activation of clearance receptors. Hepatology 17: 677-684, 1993

4. Cahill PA, Hassid A: Clearance receptor binding atrial natriuretic peptide inhibit mitogenesis and proliferation of rat aortic smooth muscle cells. Biochem Biophys Res Commun 179: 1606-1613, 1991

5. Zannetti A, Luly P, Musanti R, Baldini PM: Phosphatidylinositol-and phosphatidylcholine-dependent phospholipase $\mathrm{C}$ are involved in the mechanism of action of atrial natriuretic factor in cultured rat aortic smooth muscle cells. J Cell Physiol 170: 272-278, 1997

6. Baldini PM, De Vito P, Fraziano M, Mattioli P, Luly P, Di Nardo P: Atrial Natriuretic Factor inhibits mitogen-induced growth in rat aortic smooth muscle cells. J Cell Physiol 193: 103-109, 2002

7. Prins BA, Weber MJ, Hu RM, Pedram A, Daniels M, Levin ER: Atrial natriuretic peptide inhibits mitogen-activated protein kinase through the clearance receptor. J Biol Chem 271: 14156-14162, 1996

8. Levin ER, Frank HJL: Natriuretic peptides inhibit rat astroglial proliferation: Mediation by C receptor. Am J Physiol 261: 453-457, 1991

9. Huwiler A, Kolter T, Pfelshifter J, Sandhoff K: Physiology and pathophysiology of sphingolipid metabolism and signaling. Biochim Biophys Acta 1485: 63-99, 2000

10. Eichholtz T, Jalink K, Fahrefort I, Moolenaar WH: The bioactive phospholipids lysophosphatidic acid is released from activated platelets. Biochem J 291: 677-680, 1993

11. Anliker B, Chun J: Lysophospholipid G protein-coupled receptors. J Biol Chem 279: 20555-20558, 2004

12. Tigyi G, Dyer DL, Miledi R: Lysophosphatidic acid possesses dual action in cell proliferation. Proc Natl Acad Sci USA 91: 1908-1912, 1994

13. Jalink K, Hordijk PL, Moolenaar WH: Growth factor-like effects of lysophosphatidic acid, a novel lipid mediator. Biophys Biochim Acta 1198: 185-196, 1994

14. Inoue CN, Ko YH, Guggino WB, Forster HG, Epstein M: Lysophosphatidic acid and platelet-derived growth synergistically stimulate growth of cultured rat mesangial cells. Proc Soc Exp Biol Med 216: 370-379, 1997

15. Xu YJ, Rathi SS, Chapman DC, Arneja AS, Dhalla NS: Mechanisms of lysophosphatidic acid-induced DNA synthesis in vascular smooth muscle cells. J Cardiovasc Pharmacol 41: 381-387, 2003

16. Moolenaar WH: Lysophosphatidic acid, a multifunctional phospholipid messenger. J Biol Chem 270: 12949-12952, 1995

17. Yart A, Chap H, Raynal P: Phosphoinositide 3-kinases in lysophosphatidic acid signalling: Regulation and cross-talk with Ras/mitogen-activated protein kinase pathway. Biochim Biophys Acta 582: 107-111, 2002

18. Park HS, Lee SH, Park D, Lee JS, Ryu SH, Lee WJ, Rhee SG, Bae Y: Sequential activation of phosphatidylinositol 3 kinase, beta P Rac 1, and Nox 1 in growth factor-induced production of $\mathrm{H}_{2} \mathrm{O}_{2}$. Mol Cell Biol 24: 4384-4394, 2004

19. Chen Q, Olashaw N, Wu J: Partecipation of reactive oxygen species in the lysophosphatidic acid-stimulated mitogen-activated protein kinase kinase activation pathway. J Biol Chem 270: 28499-28502, 1995

20. Hayashi K, Takahashi M, Nishida W, Yoshida K, Ohkawa Y, Kitabatake A, Aoki J, Arai H, Sobue K: Phenotypic modulation of vascular smooth muscle cells induced by unsaturated lysophosphatidic acids. Circ Res 89: 251-258, 2001 
21. Kunsch C, Medford RM: Oxidative stress as a regulator of gene expression in the vasculature. Circ Res 85: 753-766, 1999

22. Ross RJ: The smooth muscle cell II. Growth of muscle in culture and formation of elastic fibers. J Cell Physiol 50: 171-186, 1971

23. Sambrook J, Fritsch E F, Maniatis T: Laboratory Manual. Molecular Cloning. A Second Edition, Cold Spring Harbor Laboratory Press, New York, 1989

24. Baldini PM, De Vito P, Martino A, Fraziano M, Grimaldi C, Luly P, Zalfa F, Colizzi V: Differential sensitivity of human monocytes and macrophages to ANP: A role of intracellular $\mathrm{pH}$ on reactive oxygen species production through the phospholipases involvement. J Leukoc Biol 73: 502-510, 2003

25. Zalfa F, Giorgi M, Primerano B, Moro A, Di Penta A, Reis S, Oostra B, Bagni C: The fragile $\mathrm{X}$ sindrome protein FMRP associates with $\mathrm{BC} 1$ RNA and regulates the translation of specific mRNA at synapses. Cell 112: 317-327, 2003

26. Shen $\mathrm{H}$, Shi CY, Shen Y, Ong CN: Detection of elevated reactive oxygen species level in cultured rat hepatocytes treated with aflatoxin B1. Free Rad Biol Med 21: 139-146, 1996

27. Krause U, Rider MH, Hue L: Protein kinase signalling pathway triggered by cell swelling and involved in the activation of glycogen synthase and acetyl-CoA carboxylase in isolated rat hepatocytes. J Biol Chem 271: 16668-16673, 1996

28. Lowry OH, Rosebrough NJ, Farr AL, Randal RJ: Protein measurement with the Folin phenol reagent. J Biol Chem193: 265-268, 1951

29. Ye X, Ishii I, Kingsbury MA, Chun J: Lysophosphatidic acid as a novel cell survival/apoptitic factor. Biochim Biophys Acta 1585: 108-113, 2002

30. Silberbach M, Roberts CT Jr: Natriuretic peptide signalling molecular and cellular pathways to growth regulation. Cell Signal 13: 221-231, 2001

31. Rivard A, Andreas V: Vascular smooth muscle cells proliferation in the pathogenesis of atherosclerosis cardiovascular disease. Histol Histopathol 15: 557-571, 2000
32. Siess W: Athero- and thrombogenic actions of lysophosphatidic acid and sphingosine-1-phosphate. Biochim Biophys Acta 1582: 204-215, 2002

33. Schmitz U, Thommes K, Beier I, Vetter H: Lysophosphatidic acid stimulates p21-activated kinase in vascular smooth muscle cells. Biochem Biophys Res Commun 291: 687-691, 2002

34. Gennero I, Xuereb JM, Simon MF, Girolami JP, Bascands JL, Chap H, Boneu B, Sie P: Effects of lysophosphatidic acid on proliferation and cytosolic $\mathrm{Ca}^{++}$of human adult vascular smooth muscle cells in culture. Thromb Res 94: 317-326, 1999

35. Bilzer M, Jaeschke H, Vollmar AM, Paumgartner C, Gerbers AL: Prevention of Kupffer cell-induced oxidant injury in rat liver by atrial natriuretic peptide. Am J Physiol 276: 1137-1144, 1999

36. De Vito P, Di Nardo P, Palmery M, Peluso I, Luly P, Baldini PM: Oxidant-induced $\mathrm{pHi} / \mathrm{Ca}^{2+}$ changes in rat aortic smooth muscle cells. The role of atrial natriuretic peptide. Mol Cell Biochem 252: 353-362, 2003

37. Carini R, De Cesaris MG, Splendore R, Domenicotti C, Nitti MP, Pronzato MA, Albano E: Mechanism of hepatocyte protection against hypoxic injury by atrial natriuretic peptide. Hepatology 37: 277-285, 2003

38. Cahill PA, Hassid A: Differential antimitogenic effectiveness of atrial natriuretic peptides in primary vs. subcultured rat aortic smooth muscle cells: relationship to expression of ANF-C receptors. J Cell Physiol 154: 28-38, 1993

39. Cao L, Wu J, Gardner DG: Atrial natriuretic peptide supresses the transcription of its guanylyl cyclase- linked receptor. J Biol Chem. 270 24891-24897, 1995

40. Koyasu S: The role of PI3K in immune cells. Nature Immunol 4: 313 319, 2003

41. Abbey ES, Potter LR: Lysophosphatidic acid inhibits C-type, natriuretic peptide activation of guanylyl cyclase-B. Endocrinol 144: 240-246, 2003 